DOI: https://doi.org/10.24127/ajpm.v9i3.2899

\title{
PENINGKATAN MOTIVASI BELAJAR SISWA MELALUI DISCOVERY LEARNING DENGAN GEOGEBRA PADA MATERI TRANSFORMASI
}

\author{
Lilik Firdayati \\ SMP Negeri 3 Metro, Metro, Indonesia \\ E-mail: $\quad$ firdayatililik@gmail.com
}

Received 29 June 2020; Received in revised form 17 September 2020; Accepted 29 September 2020

\begin{abstract}
Abstrak
Pembelajaran abad 21 memerlukan pemanfaatan media dalam pembelajaran, yang mengakibatkan keinginan dan minat baru, meningkatkan motivasi dan rangsangan dalam pembelajaran, bahkan berpengaruh secara psikologis kepada siswa. Media pembelajaran berbasis teknologi dapat membuat pembelajaran lebih powerfull, karena penggunaan media dalam proses pembelajaran bukan merupakan fungsi tambahan, tetapi mempunyai fungsi sebagai alat bantu untuk mewujudkan situasi pembelajaran yang aktif, efektif dan menyenangkan. Arus globalisasi yang terjadi saat ini juga mencakup aspek kemajuan dalam penggunaan teknologi informasi, diharapkan tujuan dari penggunaan geogebra dapat meningkatkan motivasi belajar matematika yang divariasi dengan model pembelajaran Discovery Learning. Penelitian ini dilakukan pada kelas IX SMP Negeri 3 Metro pada bulan November 2018 menggunakan metode Penelitian Tindakan Kelas, adapun teknik pengumpulan data menggunakan observasi dan angket motivasi. Analisisnya menggunakan teknik skala likert. Hasil penelitian ini adalah melalui Discovery Learning dengan Geogebra dapat meningkatkan motivasi belajar siswa, sehingga aktivitas belajar juga mengalami peningkatan dengan rata-rata 60,83\% pada siklus I menjadi $89,38 \%$ pada siklus III. Oleh karena itu dalam pembelajaran hendaknya guru dapat berinovasi untuk memotivasi dan meningkatkan kualitas pembelajaran dengan model yang bervariasi dan media yang sesuai, sehingga hasil belajar dapat maksimal.
\end{abstract}

Kata kunci : Discovery learning; geogebra; motivasi belajar; transformasi.

\begin{abstract}
Twenty first century instruction needs media application, which appear new demand and need, improve learning motivation and stimulate, event it affected students pshycologically. Instructional media which based on technology can create powerfull instruction, because the use of them in instructional process is not as additional function, but they function as device to create active, effective and enjoyable instructional atmosphere. Globalisation streaming nowadays also included the improvement of information technology which hoped that the application of Geogebra can improve the motivation on learning mathematic which variated in learning model Discovery Learning. The study was applied at IX grade of State Junioe High School 3 Metro in Movwmber 2018 through Classroom Action Research, The data collection was done using motivation questionnaire, The Analysys was done through likert scale. Discovery Learning of Geogebra can improve students' learning motivation so that learning activities can be improve too, the score's rate $60.83 \%$ at cycle I became $89.38 \%$ at cycle II. It can be said that teachers should do innovation to motivate and improve learning quality through variation of models and fixed media in order to gain maximum achievement of learning
\end{abstract}

Keywords : Discovery learning; geogebra; learning motivation; transformation.

This is an open access article under the Creative Commons Attribution 4.0 International License

\section{PENDAHULUAN}

Pembelajaran

abad

memerlukan pemanfaatan media dalam

pembelajaran, yang mengakibatkan keinginan dan minat baru, meningkatkan motivasi dan rangsangan dalam pembelajaran, bahkan berpengaruh secara psikologis kepada siswa. 
Keberhasilan dari proses pendidikan sangat dipengaruhi oleh pembelajaran yang berlangsung, karena merupakan inti dari proses pendidikan. Dalam meningkatkan kualitas pendidikan, seorang guru bukan hanya mentransfer ilmunya melalui buku, akan tetapi seorang guru dapat menggunakan alat bantu komputer dengan bermacammacam software yang dipadukan dengan model pembelajaran, sehingga siswa tidak hanya mendengar, melihat, tapi juga dapat melakukan sendiri proses pembelajarannya (Nursamsu \& Kusnafizal, 2017)

Dalam suatu pembelajaran, motivasi siswa mengikuti pembelajaran merupakan aspek yang sangat penting. Motivasi belajar siswa sangat dibutuhkan untuk mencapai tujuan pembelajaran, karena sebagai faktor yang banyak memberikan pengaruh terhadap keberhasilan dalam pembelajaran. Banyak cara untuk meningkatkan motivasi belajar, salah satunya melalui metode pembelajaran yang sesuai dan juga pemanfaatan media pembelajaran.

Beberapa penelitian yang dapat meningkatkan motivasi belajar yaitu menggunakan metode Discovery Learning seperti yang dilakukan oleh (Andrean et al., 2019; Farib et al., 2019; Harianti, 2018; Heryani \& Setialesmana, 2017; Jana \& Fahmawati, 2020; Listyotami et al., 2018; Masfingatin \& Murtafiah, 2020; Purwanti et al., 2016; Razi \& Mirunnisa, 2019; Vahlia, 2014). Lebih lanjut, media pembelajaran juga dapat meningkatkan motivasi siswa dalam memahami materi. Salah satu contohnya yaitu media Geogebra, seperti penelitian yang dilakukan oleh (Asmar \& Delyana, 2020; Fitriyani \& Sugiman, 2014; Nisiyatussani et al., 2018; Nurdin et al., 2019; Purwanti et al., 2016;
Purwasih et al., 2020; Sari et al., 2016; Supriadi, 2015; Syafitri et al., 2018).

Dari penelitian tersebut, belum ada yang meneliti tentang pembelajaran menggunakan metode Discovery Learning berbantu Geogebra untuk materi geometri transformasi di SMP Negeri 3 Metro. Kebaruan penelitian ini yaitu siswa SMP Negeri 3 Metro melakukan pembelajaran menggunakan metode Discovery Learning berbantu Geogebra yang harapannya dapat meningkatkan motivasi belajar siswa.

Berdasarkan hasil belajar siswa setelah Penilaian Tengah Semester (PTS) diperoleh bahwa nilai pelajaran matematika dengan rata-rata 56,72 dan di bawah nilai ketuntasan minimal yaitu 65, khususnya di kelas IX C SMPN 3 Metro, hal ini dapat terjadi karena siswa kurang tertarik dengan pelajaran matematika. Hampir seluruh siswa kehilangan konsentrasi belajar dan beberapa siswa keluar masuk kelas, bahkan tidur di dalam kelas. Selain itu, rendahnya motivasi belajar siswa dapat ditunjukkan ketika guru mengulang materi sebelumnya dan memberikan pertanyaan, akan tetapi siswa tidak bisa menjawab semua. Hal tersebut menunjukkan bahwa motivasi siswa dalam belajar yang rendah sehingga kebutuhan- kebutuhan belajar lainnya tidak dapat dipenuhi.

Banyak sekali media pembelajaran yang dapat digunakan dalam proses pembelajaran, salah satunya adalah pembelajaran menggunakan media interaktif yaitu Geogebra, sebuah software sistem geometri yang dapat mengonstruksi transformasi dan mengubahnya secara dinamis. Dengan menggunakan media pembelajaran Geogebra dapat memudahkan proses pembelajaran matematika dan membuat kegiatan 
pembelajaran menjadi menarik dan tidak monoton.

$$
\text { Geogebra memberikan }
$$

representasi beberapa obyek dalam grafik, aljabar, dan tebaran kerja yang saling terhubung secara dinamis, yang melakukan prosesnya melalui tiga perangkat keunikan operasi melalui enaktiv proses tindakan aktif, ikonik melalui gambar dan simbolis, juga melalui tanda-tanda dan bahasa. Melalui penggunaan aplikasi geogebra, siswa akan sangat terbantu dalam memahami sebuah konsep matematika. Setiap bidang dalam matematika memiliki tool yang berbeda, hal ini dikarenakan obyek kajian yang berbeda-beda. Komputer dapat berfungsi sebagai media pembelajaran yang dapat memberikan pengalaman visual kepada para siswa dalam berinteraksi dengan obyek-obyek matematika (Nur'aini et al., 2017)

Oleh karena itu, solusi untuk mengatasi motivasi belajar siswa yang rendah yaitu dengan menggunakan model discovery learning berbantu geogebra sebagai aplikasi komputer yang digunakan dalam pembelajaran matematika. Sehingga, tujuan penelitian ini yaitu untuk meningkatkan motivasi belajar siswa menggunakan model discovery learning berbantu geogebra pada materi transformasi.

\section{METODE PENELITIAN}

Penelitian tindakan kelas ini terdiri dari 3 siklus menggunakan model pembelajaran Discovery Learning dengan Geogebra, dan dilaksanakan di kelas IX C SMP Negeri 3 Metro yang berjumlah 30 orang, yang terdiri dari laki-laki 13 orang dan perempuan 17 orang. Penelitian dilaksanakan bulan Oktober - November 2018, mulai tahap persiapan sampai tahap pelaksanaan pembelajaran pada materi transformasi.
Teknik pengumpulan data menggunakan angket motivasi untuk mengukur respons siswa dalam pelaksanaan pembelajaran. Observasi untuk melihat aktivitas siswa selama pembelajaran. Data penelitian terdiri dari data kualitatif (hasil angket motivasi, hasil observasi) selama pembelajaran sumber data diperoleh langsung dari siswa saat proses pembelajaran.

Analisis data dalam penelitian ini menggunakan data kualitatif dideskripsikan dan ditransformasi secara kuantitatif dengan menentukan persentase masing-masing pengamatan. Analisis data dilakukan pada setiap data yang dikumpulkan, baik data kuantitatif maupun data kualitatif.

\section{HASIL DAN PEMBAHASAN}

Program Geogebra sangat membantu siswa untuk mempelajari konstruksi geometri. Dengan Geogebra bisa membuat konstruksi berbagai bangun geometri (dimensi 2), transformasi (Refleksi, Translasi, Rotasi, dan Dilatasi). Pada program Geogebra tersedia menu menggambar, mulai dari menggambar garis, titik sampai menggambar gabungan antara bangun datar dan garis sebagai cermin. Walaupun terlihat sederhana karena banyaknya menu yang disediakan, tetapi untuk mengkonstruks gambar ternyata tidak sederhana karena kita masih harus berpikir berbagai macam konsep geometri. Adapun Geogebra dalam komputer ditunjukkan oleh Gambar 1.

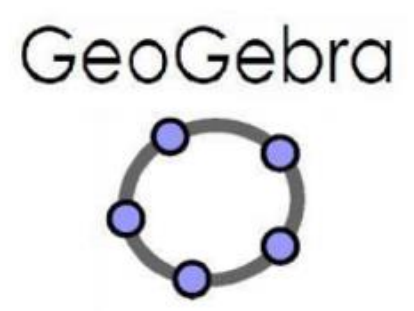

Gambar 1. Simbol Geogebra 
DOI: https://doi.org/10.24127/ajpm.v9i3.2899

Proses pembelajaran dalam penelitian ini terdiri dari tiga siklus yaitu

\section{Siklus I}

Pembelajaran pada siklus I dilaksanakan sebanyak 2 kali pertemuan, menyampaikan model pembelajaran Discovery Learning dan media yang digunakan dalam pembelajaran yaitu menggunakan aplikasi Geogebra dengan komputer. Pada pertemuan ini sebagian siswa termotivasi belajar menggunakan komputer, tapi masih ada siswa yang belum pernah buka komputer menjadi bingung, sehingga aktivitas siswa belum terlihat karena rata-rata siswa masih bingung memahami penggunaan aplikasi Geogebra dengan komputer, yang merupakan media dalam matematika yang baru di kenalkan. Siswa juga belum memahami bagaimana model Discovery Learning yang akan dilakukan dalam proses pembelajaran, sehingga ada beberapa siswa yang masih terdiam. Penggunaan waktu dalam mengembangkan lembar kegiatan dengan Geogebra juga belum sesuai dengan yang ditentukan, sehingga proses pembelajaran dalam mengkomunikasikan hasil diskusi belum maksimal.

Dari hasil pengamatan selama proses pembelajaran pada siklus I, diperoleh data dengan rata-rata aktivitas siswa 60,83\%. Hasil analisis data diperoleh bahwa 8 indikator interpretasinya sedang, karena siswa masih dalam penyesuaian belajar dengan komputer sebagai media pembelajaran, juga model Discovery Learning dengan aplikasi Geogebra merupakan hal yang baru bagi siswa. Adapun yang 11 indikator interpretasinya menunjukkan sudah baik.

Berdasarkan hasil refleksi pembelajaran pada siklus I, ada beberapa hal yang perlu diperbaiki pada pelaksanaan pembelajaran pada siklus II, yaitu : 1) Memberikan motivasi kepada siswa untuk tidak malu dalam mengajukan pertanyaan dan menjawab pertanyaan. 2) Siswa diarahkan untuk dapat membuat rangkuman setiap akhir pembelajaran 3) Siswa melaporkan hasil diskusi atau hasil latihan yang diberikan. 4) Guru memaksimalkan dalam memberikan apersepsi dan motivasi dalam pembelajaran. 5) Guru memaksimalkan sebagai fasilitator dan membimbing kesulitan belajar siswa dalam pembelajaran. 6) Penggunaan waktu yang kurang efektif dalam pembelajaran. 7) Menghindari jawaban serentak dari siswa dari pertanyaan yang diajukan. 8) Hasil belajar perlu ditingkatkan. 9) Kerja sama siswa dalam kelompok belum maksimal.10) Semua siswa diharapkan menyatakan setuju dalam penggunaan aplikasi Geogebra dalam pembelajaran transformasi, setelah terbiasa menggunakannya.

\section{Siklus II}

Pembelajaran pada siklus II dilaksanakan 2 kali pertemuan, mengingatkan kembali penggunaan model pembelajaran Discovery Learning dan media yang digunakan dalam pembelajaran yaitu menggunakan aplikasi Geogebra dengan komputer. Materinya adalah translasi (pergeseran) bangun datar. Pada pertemuan ini motivasi dan aktivitas siswa sudah mulai terlihat, karena rata-rata siswa sudah mulai memahami penggunaan aplikasi Geogebra untuk menurunkan rumus translasi dengan mengikuti lembar kegiatan yang telah dibagikan.

Aktivitas siswa dalam proses pembelajaran pada siklus II tercapai dalam rata-rata $76,67 \%$. Setiap indikator sudah mengalami peningkatan persentase keaktifan siswa. Indikator pertama dalam proses pembelajaran 
yaitu mengajukan pertanyaan pada guru rata-rata persentase dari siklus I, 96,67\% menjadi $100 \%$ pada siklus II.

Berdasarkan hasil refleksi pada siklus II, ada beberapa kelemahan yang perlu di perbaiki dan dimaksimalkan pada pelaksanaan proses pembelajaran pada siklus III antara lain : 1) Siswa masih kurang percaya diri untuk menjawab setiap pertanyaan guru yang diajukan. 2) Guru perlu meningkatkan lagi dalam memantau kesulitan belajar siswa. 3) Guru kurang memperhatikan waktu yang digunakan, sampai lupa tidak memberikan pekerjaan rumah. 4) Jawaban serentak dari siswa masih sering terjadi, sehingga untuk mengukur kemampuan siswa secara lisan tidak terlihat. Dengan demikian pelaksanaan pembelajaran pada siklus II sudah mengalami peningkatan aktivitas dan motivasi belajarnya.

\section{Siklus III}

Pembelajaran pada siklus III dilaksanakan 2 kali pertemuan, membahas materi rotasi yang searah jarum jam dan berlawanan arah jarum jam. Masih dengan menggunakan model Discovery Learning dengan Geogebra menurunkan rumus rotasi yang searah dan berlawanan arah jarum jam untuk sudut $90^{\circ}$ dan $180^{\circ}$ secara kelompok. Pada pertemuan pertama ini siswa semakin semangat dalam belajarnya, sehingga siswa banyak berkreasi untuk gambar bangun datarnya, sehingga aktivitasnya juga meningkat, terutama dalam penggunaan Geogebra dengan komputer, dalam diskusi kelompok makin hidup, banyak pertanyaan yang muncul dari setiap kelompok. Dilanjutkan dengan latihan soal yang berkaitan dengan rotasi dari bangun datar.

Aktivitas siswa terlihat mengalami peningkatan dengan rata-rata
$89,36 \%$, bahwa proses pembelajaran pada siklus III interpretasi siswa sudah meningkat secara keseluruhan, kecuali satu indikator membuat catatan yang di tempel di kamar, rata-rata siswa dalam hal ini sudah tidak telaten lagi untuk membuat hal-hal penting untuk ditempel di tembok kamarnya. Karena bahan literasi digital lebih menarik siswa untuk dibaca dan lihat.

Berdasarkan hasil refleksi pada siklus III, bahwa proses pembelajaran sudah seperti yang diharapkan. Aktivitas, motivasi siswa dan kegiatan guru sudah menunjukkan peningkatan, walau kadang masih ada siswa yang kurang fokus, kurang bersemangat tapi tidak mengurangi bermaknanya pembelajaran yang sudah dilaksanakan. Kelemahan dan kekurangan setiap proses pembelajaran itu akan menjadi acuan perbaikan untuk kegiatan berikutnya.

Meningkatnya motivasi belajar diiringi dengan meningkatnya aktivitas dalam pembelajaran yang ditunjukkan dalam Tabel 1. Dari Tabel 1 menunjukkan bahwa, dalam proses pembelajaran menggunakan model Discovery Learning dengan Geogebra dalam materi transformasi menunjukkan peningkatan, dalam menjawab pertanyaan meningkat $10 \%$, menjawab pertanyaan meningkat $20 \%$, bekerja sama dalam kelompok $31,66 \%$, bertukar pendapat antar teman satu kelompok $35 \%$, siswa dalam menggunakan komputer $20 \%$, membuat bangun datar dan transformasinya $55 \%$, dan siswa yang melaporkan hasil diskusi meningkat 46,67\%. Kenaikan persentase dari siklus ke siklus dikarenakan setiap kelemahan dan kekurangan yang ada pada siklus sebelumnya diperbaiki untuk pelaksanaan siklus berikutnya. 
DOI: https://doi.org/10.24127/ajpm.v9i3.2899

Tabel 1. Peningkatan aktivitas siswa dalam proses pembelajaran.

\begin{tabular}{|c|c|c|c|c|}
\hline \multirow{2}{*}{ No. } & \multirow{2}{*}{ Aktivitas siawa } & \multicolumn{3}{|c|}{ Siklus } \\
\hline & & I & II & III \\
\hline 1 & $\begin{array}{l}\text { Mengajukan } \\
\text { Pertanyaan }\end{array}$ & 98,33 & 100,00 & 100,00 \\
\hline 2 & $\begin{array}{l}\text { Menjawab } \\
\text { pertanyaan }\end{array}$ & 73,33 & 81,67 & 83,33 \\
\hline 3 & $\begin{array}{l}\text { Mengerjakan } \\
\text { lembar kegiatan } \\
\text { yang diberikan }\end{array}$ & 70,00 & 80,00 & 90,00 \\
\hline 4 & $\begin{array}{l}\text { Bekerja sama } \\
\text { dalam kelompok }\end{array}$ & 51,67 & 66,67 & 83,33 \\
\hline & $\begin{array}{l}\text { Bertukar } \\
\text { pendapat antar } \\
\text { teman } 1\end{array}$ & 28,33 & 56,67 & 63,33 \\
\hline 5 & kelompok & & & \\
\hline 6 & $\begin{array}{l}\text { Menggunakan } \\
\text { komputer }\end{array}$ & 80,00 & 96,67 & 100,00 \\
\hline 7 & $\begin{array}{l}\text { Membuat bangun } \\
\text { datar dan } \\
\text { transformasinya }\end{array}$ & 40,00 & 70,00 & 95,00 \\
\hline 8 & $\begin{array}{l}\text { Melaporkan hasil } \\
\text { diskusi }\end{array}$ & 45,00 & 61,67 & 91,67 \\
\hline & Rata-rata (\%) & 60,83 & 76,67 & 89,38 \\
\hline
\end{tabular}

Motivasi belajar siswa dari siklus I sampai III mengalami peningkatan (Tabel 2), bahkan motivasi belajar di akhir siklus sangat tinggi. Artinya pembelajaran menggunakan model Discovery Learning berbantu Geogebra dapat meningkatkan motivasi belajar siswa secara signifikan. Salah satuindikator motivasi belajar siswa yaitu siswa mempelajari matematika dengan penuh semangat.

Dalam penelitian relevan dikatakan bahwa dengan menggunakan aplikasi Geogebra dalam pembelajaran kepada siswa SMP dapat memberikan pandangan yang berbeda terhadap matematika, yang selama ini dianggap sulit dan membosankan dapat menjadi menyenangkan, dan siswa sangat antusias dalam menyelesaikan tugastugas matematika, sehingga minat dan motivasi siswa menjadi meningkat (Jana \& Fahmawati, 2020).
Tabel 2. Peningkatan motivasi siswa dalam proses pembelajaran.

\begin{tabular}{|c|c|c|c|c|}
\hline \multirow{2}{*}{ No } & \multirow{2}{*}{ Pernyataan } & \multicolumn{3}{|c|}{ Siklus } \\
\hline & & I & II & III \\
\hline 1 & $\begin{array}{l}\text { Matematika } \\
\text { dipelajari dengan } \\
\text { penuh semangat }\end{array}$ & 82,50 & 90,83 & 92,50 \\
\hline 2 & $\begin{array}{l}\text { Saya merasa senang } \\
\text { dan puas bila } \\
\text { berhasil } \\
\text { menyelesaikan soal } \\
\text { matematika }\end{array}$ & 81,67 & 97,50 & 97,50 \\
\hline 3 & $\begin{array}{l}\text { Saya ingin } \\
\text { berprestasi dalam } \\
\text { pelajaran matematika }\end{array}$ & 74,17 & 88,33 & 89,17 \\
\hline 4 & $\begin{array}{l}\text { Pelajaran } \\
\text { Matematika itu } \\
\text { menarik jika } \\
\text { menggunakan media } \\
\text { pembelajaran }\end{array}$ & 80,00 & 89,17 & 90,83 \\
\hline 5 & $\begin{array}{l}\text { Saya mengikuti } \\
\text { pelajaran matematika } \\
\text { di kelas dengan baik }\end{array}$ & 80,00 & 81,67 & 84,17 \\
\hline 6 & $\begin{array}{l}\text { Model dan media } \\
\text { yang digunakan guru } \\
\text { menarik bagi saya }\end{array}$ & 60,83 & 89,17 & 89,17 \\
\hline 7 & $\begin{array}{l}\text { Saya aktif berdiskusi } \\
\text { dengan teman saat } \\
\text { belajar matematika }\end{array}$ & 75,00 & 82,50 & 83,33 \\
\hline 8 & $\begin{array}{l}\text { Saya mendengarkan } \\
\text { dengan sungguh- } \\
\text { sungguh penjelasan } \\
\text { materi yang } \\
\text { disampaikan oleh } \\
\text { guru }\end{array}$ & 84,17 & 86,67 & 87,50 \\
\hline 9 & $\begin{array}{l}\text { Saya belajar } \\
\text { matematika tidak } \\
\text { hanya saat ulangan }\end{array}$ & 75,00 & 76,67 & 76,67 \\
\hline 10 & $\begin{array}{l}\text { Jika ada ulangan } \\
\text { matematika saya } \\
\text { ingin mendapatkan } \\
\text { nilai tertinggi dan } \\
\text { lulus ujian nasional } \\
\text { dengan nilai terbaik }\end{array}$ & 93,33 & 95,00 & 95,83 \\
\hline & Rata-rata (\%) & 78,67 & 87,75 & 88,67 \\
\hline
\end{tabular}

Perpaduan media pembelajaran dengan model pembelajaran yang tepat dapat meningkatkan motivasi dan aktivitas siswa meningkat seperti yang disampaikan (Rudyanto, 2016) bahwa dalam pembelajaran Discovery Learning menuntut siswa untuk menemukan hal baru, proses untuk menemukan hal baru diperlukan kreativitas, sehingga dengan sintak yang ada di dalamnya dapat meningkatkan berpikir kreatif siswa dan 
dapat meningkatkan pemahaman sains, produktif dalam berpikir kreatif, dan siswa menjadi terampil dalam memperoleh dan menganalisis informasi.

Penggunaan model pembelajaran

Discovery Learning, ingin merubah kondisi belajar yang pasif menjadi aktif dan kreatif. Mengubah pembelajaran yang teacher oriented ke student oriented. Mengubah modus Ekspositori, siswa hanya menerima informasi secara keseluruhan dari guru ke modus Discovery, siswa menemukan informasi sendiri. Dalam mengaplikasikan model Discovery Learning guru berperan sebagai pembimbing dengan memberikan kesempatan kepada siswa untuk belajar secara aktif, guru harus dapat membimbing dan mengarahkan kegiatan belajar siswa sesuai dengan tujuan.

Motivasi merupakan faktor dari dalam diri siswa yang mempengaruhi keinginannya untuk melakukan proses pembelajaran. Motivasi sangat penting dalam proses pembelajaran, untuk mencapai suatu keberhasilan proses belajar siswa. setiap siswa pasti memiliki kebutuhan dan keinginan untuk mencapai tujuan tersebut. Motivasi sebagai penggerak untuk mencapai tujuannya, sehingga apabila motivasi tersebut tidak ada secara tidak langsung proses pembelajaran tidak akan maksimal dan menjadi lemah.

Proses Belajar aktif seharusnya ditunjang juga dengan memperhatikan perkembangan teknologi informasi dan komunikasi (TIK). TIK akan dapat membantu jalannya pembelajaran aktif. Oleh karena itu sudah saatnya sekolah merancang, memanfaatkan, dan mengembangkan proses pembelajaran dengan TIK. Pembelajaran yang aktif perlu dukungan administrasi yang efektif, efisien, dan dapat dipertanggungjawabkan. Agar kegiatan administrasi sekolah dapat juga lebih cepat dan optimal perlu memanfaatkan TIK (Warsihna, 2013).

Hasil penelitian ini sejalan dengan penelitian yang dilakukan oleh (Andrean et al., 2019; Heryani \& Setialesmana, 2017; Masfingatin \& Murtafiah, 2020; Nur'aini et al., 2017; Nurdin et al., 2019; Purwanti et al., 2016; Razi \& Mirunnisa, 2019; Rudyanto, 2016; Syafitri et al., 2018; Vahlia, 2014). Dampak yang timbul dari penelitian ini yaitu motivasi siswa dalam mempelajari transformasi meningkat signifikan akibat pembelajaran menggunakan Discovery Learning berbantu Geogebra.

\section{KESIMPULAN DAN SARAN}

Dari hasil penelitian yang telah dilakukan dapat disimpulkan bahwa model Discovery Learning berbantu Geogebra dapat meningkatkan aktivitas siswa dalam pembelajaran, yang ditunjukkan dengan peningkatan persentase dari siklus ke siklus dan dapat meningkatkan motivasi belajar siswa dalam pembelajaran matematika, pembelajaran yang menyenangkan karena dapat berkreasi dengan Geogebra. Berdasarkan hasil penelitian tersebut, maka saran yang dapat diberikan adalah penggunaan model Discovery Learning dengan Geogebra dalam pembelajaran matematika hendaknya digunakan sebagai salah satu alternatif yang mampu mengaktifkan siswa belajar lebih bermakna, yang pada akhirnya meningkatkan aktivitas dan motivasi belajar matematika. Oleh karena itu seorang guru harus kreatif memadukan model dengan media pembelajaran untuk menciptakan pembelajaran yang inovatif, efektif dan menyenangkan. 
DOI: https://doi.org/10.24127/ajpm.v9i3.2899

DAFTAR PUSTAKA

Andrean, N. J., Noer, S. H., \& Asmiati. (2019). Pengembangan

Pembelajaran Penemuan

Terbimbing Untuk Meningkatkan Kemampuan Berpikir Reflektif dan Kemandirian Belajar Siswa. AKSIOMA: Jurnal Program Studi Pendidikan Matematika, 8(2), 270 278.

Asmar, A., \& Delyana, H. (2020). Berpikir Kritis Melalui Penggunaan Software Geogebra. AKSIOMA: Jurnal Program Studi Pendidikan Matematika, 9(2), 221-230.

Farib, P. M., Ikhsan, M., \& Subianto, M. (2019). Proses berpikir kritis matematis siswa sekolah menengah pertama melalui discovery learning. Jurnal Riset Pendidikan Matematika, 6(1), 99-117.

Fitriyani, W., \& Sugiman, S. (2014). Pengembangan Perangkat Pembelajaran Teorema Pythagoras Dengan Pendekatan Ideal Berbantuan Geogebra. Jurnal Riset Pendidikan Matematika, 1(2), 268283.

https://doi.org/10.21831/jrpm.v1i2. 2681

Harianti, F. (2018). Pengaruh Model Pembelajaran Guided Discovery Learning Terhadap Kemampuan Pemahaman Dan Hasil Belajar Siswa Materi Operasi Aljabar Kelas VII SMP. MUST: Journal of Mathematics Education, Science and Technology, 3(1), 82-91.

Heryani, Y., \& Setialesmana, D. (2017). Penggunaan Model Discovery Learning terhadap Peningkatkan Kemampuan Koneksi dan Komunikasi Matematik. Al-Jabar: Jurnal Pendidikan Matematika, 8(1), 43-52.

Jana, P., \& Fahmawati, A. A. N. (2020). Model Discovery Learning Untuk
Meningkatkan Kemampuan Pemecahan Masalah. AKSIOMA: Jurnal Program Studi Pendidikan Matematika, 9(1), 213-220.

Listyotami, M. K., Noer, S. H., \& Haenilah, E. Y. (2018). Discovery Learning to Develop Student Reflective Thinking Ability and Self-Efficacy. Al-Jabar: Jurnal Pendidikan Matematika, 9(1), 7384.

Masfingatin, T., \& Murtafiah, W. (2020). Exploring The Creative Mathematical Reasoning of Mathematics Education Student Through Discovery Learning. AKSIOMA: Jurnal Program Studi Pendidikan Matematika, 9(2), 296305.

Nisiyatussani, Ayuningtyas, V., Fathurrohman, M., \& Anriani, N. (2018). GeoGebra applets design and development for junior high school students to learn quadrilateral mathematics concepts. Journal on Mathematics Education, 9(1), 27-40.

Nur'aini, I. L., Harahap, E., Badruzzaman, F. H., \& Darmawan, D. (2017). Pembelajaran Matematika Geometri Secara Realistis Dengan GeoGebra. Jurnal Matematika, 16(2), 1-6. https://doi.org/10.29313/jmtm.v16i 2.3900

Nurdin, E., Ma, A., Amir, Z., \& Azmi, M. P. (2019). Pemanfaatan video pembelajaran berbasis Geogebra untuk meningkatkan kemampuan pemahaman konsep matematis siswa SMK. 6(1), 87-98.

Nursamsu, N., \& Kusnafizal, T. (2017). Pemanfaatan Media Pembelajaran Ict Sebagai Kegiatan Pembelajaran Siswa Di Smp Negeri Aceh Tamiang. Jurnal IPA \& Pembelajaran IPA, 1(2), 165-170. 
DOI: https://doi.org/10.24127/ajpm.v9i3.2899

https://doi.org/10.24815/jipi.v1i2.9 691

Purwanti, R. D., Pratiwi, D. D., \& Rinaldi, A. (2016). Pengaruh Pembelajaran Berbantuan GeoGebra Terhadap Pemahaman Konsep Matematis ditinjau dari Gaya Kognitif. Al-Jabar: Jurnal Pendidikan Matematika, 7(1), 115122.

https://doi.org/https://doi.org/10.24 042/ajpm.v7i1.137

Purwasih, R., Sariningsih, R., \& Sari, I. P. (2020). Self Efficacy Terhadap Kemampuan High Order Thinking Mathematics Siswa Melalui Pembelajaran Berbantuan Softwere Geogebra. AKSIOMA: Jurnal Program Studi Pendidikan Matematika, 9(1), 166-173. https://doi.org/10.24127/ajpm.v9i1. 2663

Razi, Z., \& Mirunnisa. (2019). Model Discovery Learning Berbantuan Software Maple Terhadap Kemampuan Pemahaman Matematis. AKSIOMA: Jurnal Program Studi Pendidikan Matematika, 8(3), 520-527.

Rudyanto, H. E. (2016). Model Discovery Learning Dengan Pendekatan Saintifik Bermuatan Karakter Untuk Meningkatkan Kemampuan Berpikir Kreatif. Premiere Educandum: Jurnal Pendidikan Dasar Dan Pembelajaran, 4(01), 41-48. https://doi.org/10.25273/pe.v4i01.3 05
Sari, F. K., Farida, \& M.Syazali. (2016). Pengembangan Media Pembelajaran (Modul) berbantuan Geogebra Pokok Bahasan Turunan. Jurnal Pendidikan Matematika, 7(2), 135-152. http://ejournal.radenintan.ac.id/inde x.php/al-jabar/article/view/24

Supriadi, N. (2015). Pembelajaran Geometri Berbasis Geogebra Sebagai Upaya Meningkatkan Kemampuan Komunikasi Matematis. Al-Jabar: Jurnal Pendidikan Matematika, 6(2), 99109.

http://ejournal.upi.edu/index.php/jp manper/article/view/00000\%0AImp ak

Syafitri, Q., Mujib, Anwar, C., Netriwati, \& Wawan. (2018). The Mathematics Learning Media uses Geogebra on the Basic Material of Linear Equations. Al-Jabar: Jurnal Pendidikan Matematika, 9(1), 9-18.

Vahlia, I. (2014). Ekperimentasi Model Pembelajaran Discovery dan Group Investigation terhadap Prestasi Belajar matematika Ditinjau dari Kreativitas Siswa. AKSIOMA: Jurnal Program Studi Pendidikan Matematika, 3(2), 43-54.

Warsihna, J. (2013). Pemanfaatan TIK untuk Pendidikan (E-Learning) di SMP. Jurnal Teknodik, 17(1), 523532. 